\title{
Heavy Metal Removal from Commercially-available Fruit Juice Packaged Products by Citric Acid
}

\author{
SHABNAM MOHAMMADI ${ }^{1}$ and PARISA ZIARATI ${ }^{2 *}$ \\ 'Department of Food Sciences and Technology, Pharmaceutical Sciences Branch, \\ Islamic Azad University (IAUPS), Tehran, Iran. \\ ${ }^{2}$ Department of Medicinal Chemistry, Pharmaceutical Sciences Branch, \\ Islamic Azad University (IAUPS), Tehran, Iran. \\ *Corresponding author E-mail: ziarati.p@iaups.ac.ir
}

http://dx.doi.org/10.13005/ojc/310148

(Received: January 10, 2015; Accepted: February 08, 2015)

\begin{abstract}
There has been an increasing trend in the production and consumption of local and imported fruit juices in Iran. The presence of impurities and foreign matter in finished products for human consumption is of great concern because they present health hazards when they exceed beneficial limits. The manufacture of juices requires special attention in terms of purity and the sources of water and its purification are crucial for maintaining quality and safety. Biosorption can be deûned as the removal of metal or metalloid species, compounds and particulates from solution by biological material. citric acid content of beverages may be useful in nutrition therapy for calcium urolithiasis, achieving therapeutic urinary citrate concentration is one clinical target in the medical management of calcium urolithiasis. Information on the citric acid content of fruit juices and commercially-available formulations is not widely known. Levels of heavy metals: Lead, Cadmium and Nickel in 180 selected fruit juice commercially available packaged samples (Pineapple, Orange, Mango, Tropical, Cherry\& Grape) purchased from Tehran local Market in 2014. Heavy metals were determined using atomic absorption spectrophotometer (AAS) by wet digestion method in Pharmaceutical Sciences Branch, Islamic Azad University Tehran-Iran. From the obtained result $\mathrm{Ni}, \mathrm{Cd}$ and $\mathrm{Pb}$ were detectable in $85 \%$ of samples especially in Mango and Tropical juices. The efficiency removal of Nickel, lead and Cadmium and neutralization of calculus contain of juice by Citric acid as a chelating were carried out by using of Atomic Absorption Spectrophotometry technique. The result demonstrated the complexation formulating between the citric acid and heavy metals. The high efficiency of Citric acid played an important role in removal of lead and cadmium in addition to this removal were increased by increasing the citric acid. The enhancing of citric acid in removal of lead and cadmium caused to create a slightly tart, refreshing flavor and balance sweetness.
\end{abstract}

Key words: Heavy metal removal, Citric acid, fruit Juice.

\section{INTRODUCTION}

There are many products obtained from fruits, including fruit juice, canned, dried, and frozen fruit; pulps; and marmalades. Fruit composition is mainly water $(75-90 \%)$, which is mainly found in vacuoles, giving turgor (textural rigidity) to the fruit tissue. Juice is the liquid extracted from the cells of 
mature fruits. Fruit cell wall is made of cellulose, hemicellulose, pectic substances, and proteins ${ }^{1}$. Fruit Juices and portable water and also tea are the most widespread beverages in the habitual diet, and they contribute significantly to trace element dietary intake. Fruit juices are a highly appreciated, tasty food and usually have exceptional nutritional qualities. However, they can be a potential source of toxic elements, some of them having an accumulative effect or leading to nutritional problems due to the low concentrations of essential elements, justifying the control of mineral composition in juice ${ }^{2-4}$. In Iran just like most of other countries fruit juices are the usual beverages, and used in most of the festivals, ceremonies and celebrations and even in hospitals and schools. Fruit juices found in all retail markets and mostly derived from citrus fruit but some chemicals are added in their formulation. They are served in dinner or lunch with biscuits, snacks or pastries and occasionally with breads. However, they can be a potential source of toxic elements, some of them having an accumulative effect or leading to nutritional problems due to the low concentrations of essential elements, justifying the control of mineral composition in juice ${ }^{2-4}$. Chemicals may be encountered as reactants, solvents, catalysts, inhibitors, as starting materials, finished products, by-products, contaminants, or off-specification products. They may vary from pure, single substances to complex proprietary formulations. An exposure to a specific chemical in relatively low concentrations over a period may result in chronic effects. At higher concentrations, the effects may be acute. Some chemicals produce local damage at their point of contact with, or entry into, the body; others produce systemic effects, i.e. they are transported within the body to various organs before exerting an adverse effect ${ }^{1}$. The concentration of heavy metals in fruit juice products varies depending on their origin, storage condition and processing technologies ${ }^{5}$. Heavy metal contamination has become one of the major issues of public health concern, but still has not received much research attention in many developing countries such as Iran especially in case of fruit juices. The heavy metal and trace element levels of fruit juices may be expected to be influenced by the nature of the fruit, the weather conditions, the mineral composition of the soil from which it originated according to the geographical conditions, the composition of the irrigation water, the agricultural practices such as the types and amounts of fertilizers used, and other factors such as water used in the fruit juices reconstruction in the manufacturing process $^{6}$.

Citrates have been reported to assist in platting of copper ${ }^{7}$, nickel ${ }^{8}$, chromium and lead ${ }^{9}$ and various heavy metals ${ }^{10}$. Citric acid is also an preferred nucleating or blowing agent in polymeric foams for food and beverage use and its esters are used as plasticizers in the preparation of polymer compositions ${ }^{10}$. Over half of global consumption of citric acid is used for the beverage industry. The food industry consumes about 15$20 \%$, followed by detergent and soaps (15-17\%), pharmaceuticals and cosmetics (7-9\%), and industrial uses $(6-8 \%)^{11}$. Citric acid which was used in carry study is one of the organic acids commonly used as chelating agents and neutralization ${ }^{12,13}$, Citric acid form square planer complex with heavy metals through binding to citrate anions with cations. Information on the citric acid content of fruit juices and commercially-available formulations is not widely known. $60 \%$ of citric acid product is mainly used in the food and beverage industry, because of its general recognition as safe having pleasant taste, high water solubility and chelating and buffering properties. Citric acid is used extensively in carbonated beverages to provide taste and complement fruit and berry flavors. It also increases the effectiveness of antimicrobial preservatives. The amount of acid used depends on the flavor of the product. It usually may vary from 1.5 to $5 \%^{14-18}$. Citric acid also inhibits color and flavor deterioration in frozen fruit ${ }^{19}$. Amounts in concentration of 0.005 $0.02 \%$ citric acid are used as an antioxidant synergism in fats, oils and fat containing foods ${ }^{10}$. According to the last researches by author on food safety and obvious documented findings in presence of heavy metals in vegetables and fruits during last decade ${ }^{20-25}$ and this fact that food can be contaminated with heavy metals by ingestion of contaminated or polluted food and water, achieving the safe solution to remove or reduce these chemical hazards is the main goal of this study. Exposure of people to toxic chemicals such as cadmium and lead could be probably reduced by appropriate method. Due to the first hypothesis of capability of 
citric acid form square planer complex with heavy metals through binding to citrate anions with heavy metal cations, we decide to comprehend this compound to remove the possible heavy metals being exist in packaged fruit juice.

\section{The objectives of this study were}

a) To determine the concentration of heavy metals $(\mathrm{Pb}, \mathrm{Ni}$ and $\mathrm{Cd})$ in most known fruit juices available commercially in the form of packaged in Tehran market (Iran), using Atomic Absorption Spectrophotoscopy (AAS)

b) To compare these results with the maximum admissible limit set in drinking water by different international organizations: United States Environmental Protection Agency (USEPA) and World Health Organization (WHO) and also national standard.

c) To evaluate the citric acid efficiency in removal the heavy metal containments in packaged fruit juice products.

d) Investigating the role of citric acid as chelating agent in order to remove heavy metals especially nickel, lead and cadmium and find the optimum concentration of citric acid for removing process .

\section{MATERIAL AND METHODS}

\section{Sampling method}

180 varieties of $200 \mathrm{ml}$ packaged fruit juices from 5 recognized manufacturers (Pineapple, Orange, Mango, Tropical, Cherry and Grape) were investigated for the presence of heavy metals and study for removing possible chemical contamination, purchased from recognized market of Tehran from the month of September to December 2014. At least 5 samples of each category were analyzed to overcome sampling bias. $\mathrm{pH}$ was determined using digital $\mathrm{pH}$ meter (Inolab digital $\mathrm{pH}$ meter). .Moisture and ash contents of fruit juices were determined using standard AOAC methods ${ }^{26}$.

Heavy metals: lead, Nickel and cadmium in each sample were determined ${ }^{27}$. In order to studying in treating samples as well as determination of heavy metals each samples divided into half $(100 \mathrm{ml})$ after shaking for two steps of experiment. In this survey, $2.5 \mathrm{~mL}$ of $69 \%$ pure Merck nitric acid and $0.5 \mathrm{~mL}$ Hydrochloric acid
$36.5 \%$ Merck were added to $2.5 \mathrm{~mL}$ of fruit juices in a Teflon receptacle tightly closed. The whole system was put in an oven at $180^{\prime \prime ~} \mathrm{C}$ for 12 hours. A colorless solution resulted, and deionized water was added up to $50 \mathrm{~mL}$. Thus, the fruit juices samples were diluted 1: $20 \mathrm{v} / \mathrm{v}$. For each sample analysis three replicates were measured in order to assure the control quality of our measurements. Heavy metals were determined using atomic absorption spectrophotometer (AAS) by wet digestion method in Pharmaceutical Sciences Branch, Islamic Azad University Tehran-Iran. Heavy Metals were analyzed using calibration curves made up of at least five standards with the minimum values of determination coefficient $\left(\mathrm{R}^{2}\right)$ of $\mathrm{Pb}, \mathrm{Ni}$ and $\mathrm{Cd}$.

Different parameters are employed for elemental analysis of heavy metals. The flame fuel used is air-acetylene mixture. The sensitivity of the instrument is 0.001 . Appropriate quality assurance procedures and all necessary precautions were taken to avoid any possible contamination of the sample as per the AOAC guidelines precaution were carried out to ensure reliability of the result. Samples were carefully handled to avoid contamination $22-27$.

\section{Treatment of Fruit Juice Samples with Citric acid}

The Fruit Juice samples (100 $\mathrm{mL}$ each) were separately measured into clean dried and labeled plastic containers. Citric acid by the different concentrations: $0.005 \%, 0.01 \%, 0.015 \%, 0.02 \%$ and $0.05 \%$ were introduced into the samples at a concentration of $0.2 / 100 \mathrm{ml}$ and stirred for 15 minutes. Two controls were also obtained by treating one fruit juice sample with the citric acid solvent used for the removal heavy metals from the juices $(0.2 \mathrm{ml} / 100 \mathrm{~mL})$ while the second was untreated. The plastic containers were firmly covered and shaken to mix the citric acid and fruit juice. The precipitations were separated and filtered by Quantitative Ash less Filter Paper: Whatman - Grade 41. The treated and control samples were stored under ambient conditions. Initial assessments of the removal levels of the heavy metals from samples were carried out after 15 minutes. Sampling and subsequent analysis were carried out to monitor the changes in parameters associated with the formation of complexes in the stored treated samples. 


\section{Statistical Method}

State differences on the basis of the states: fruit juice samples and treated samples by citric acid were determined by student t-test. The changes were calculated by one way Anova and for analysis of the role of multiple factors univariate analysis was used by SPSS 18. Probability values of $<0.05$ were considered significant.

\section{RESULTS}

The $\mathrm{pH}$, total carbohydrate and sugar content of these 6 fruit juices are almost the same and $\mathrm{pHd}$ " 3.4. The main sugars present in fruit juices are sucrose, glucose and fructose generally but the content of these three types of sugars is different in fruit juices according to the kind of fruit and brand too.
$\mathrm{Pb}$ level in the fruit juices ranged from $0.0285 \pm 0.0001$ to $1.9621 \pm 0.0013(\mathrm{mg} / \mathrm{l} \pm \mathrm{SD})$. Concentrations of $\mathrm{Pb}$ in mango juice and $\mathrm{Ni}$ in pineapple and tropical juice were relatively high. $\mathrm{Cd}$ was not detected in the most of selected juices. Additionally, $\mathrm{Pb}, \mathrm{Cd}$ and $\mathrm{Ni}$ were not detected in $90 \%$ cherry juice samples from different brands but were present in most of mango and tropical samples. However, the cadmium levels of selected fruit juices were within permissible levels except for mango juice. The range and arithmetic mean concentration of $\mathrm{Pb}$ and $\mathrm{Cd}$ in different fruit juices are also given in table 2 as average of three replicates of the individual fruit juices. Each code belongs to a special brand.

Heavy metal concentrations in treated samples mostly were below the recommended

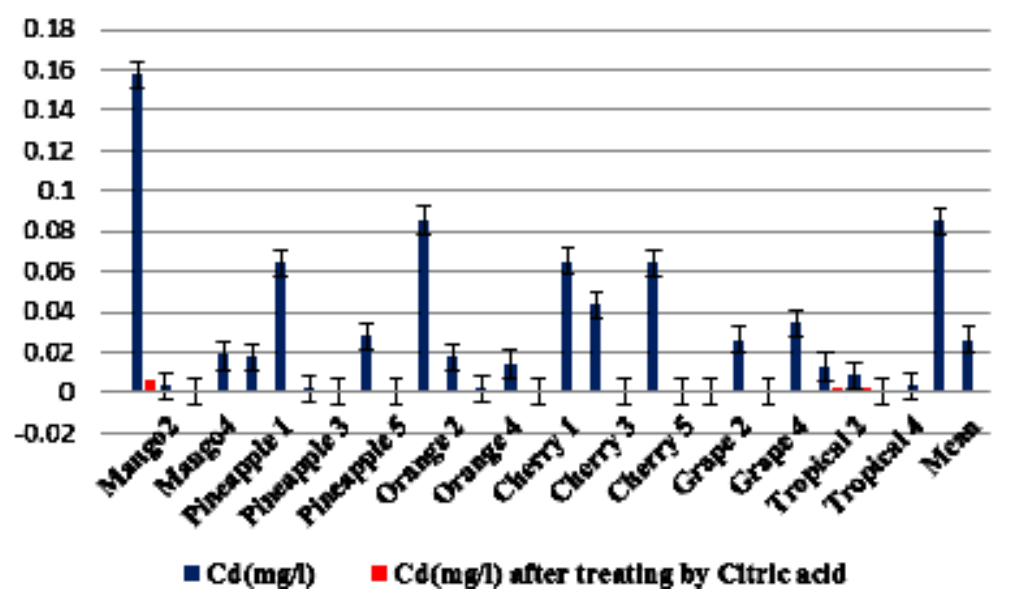

Fig. 1: Cadmium content(mg/L) in treated and untreated fruit juice samples

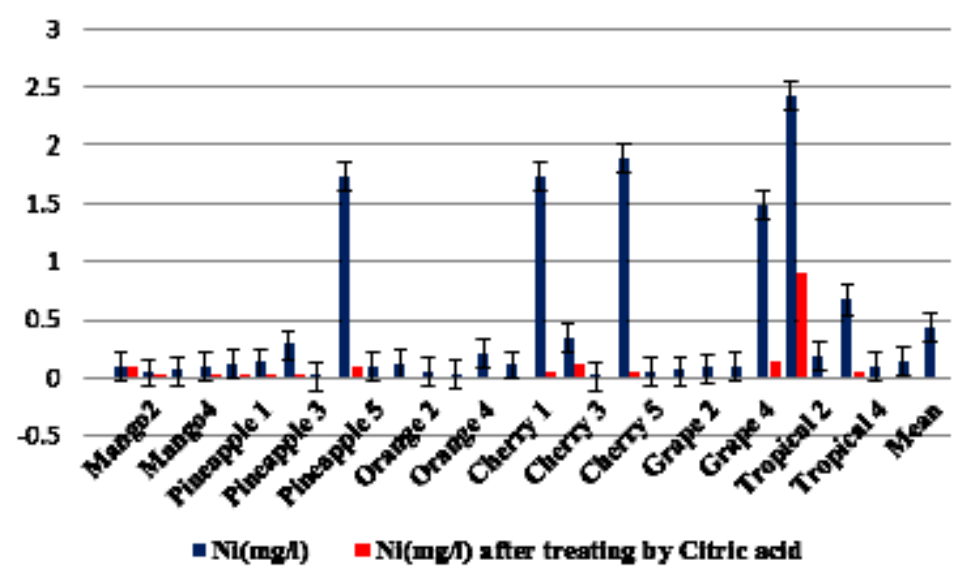

Fig. 2: Nickel content $(\mathrm{mg} / \mathrm{L})$ in treated and untreated fruit juice samples 


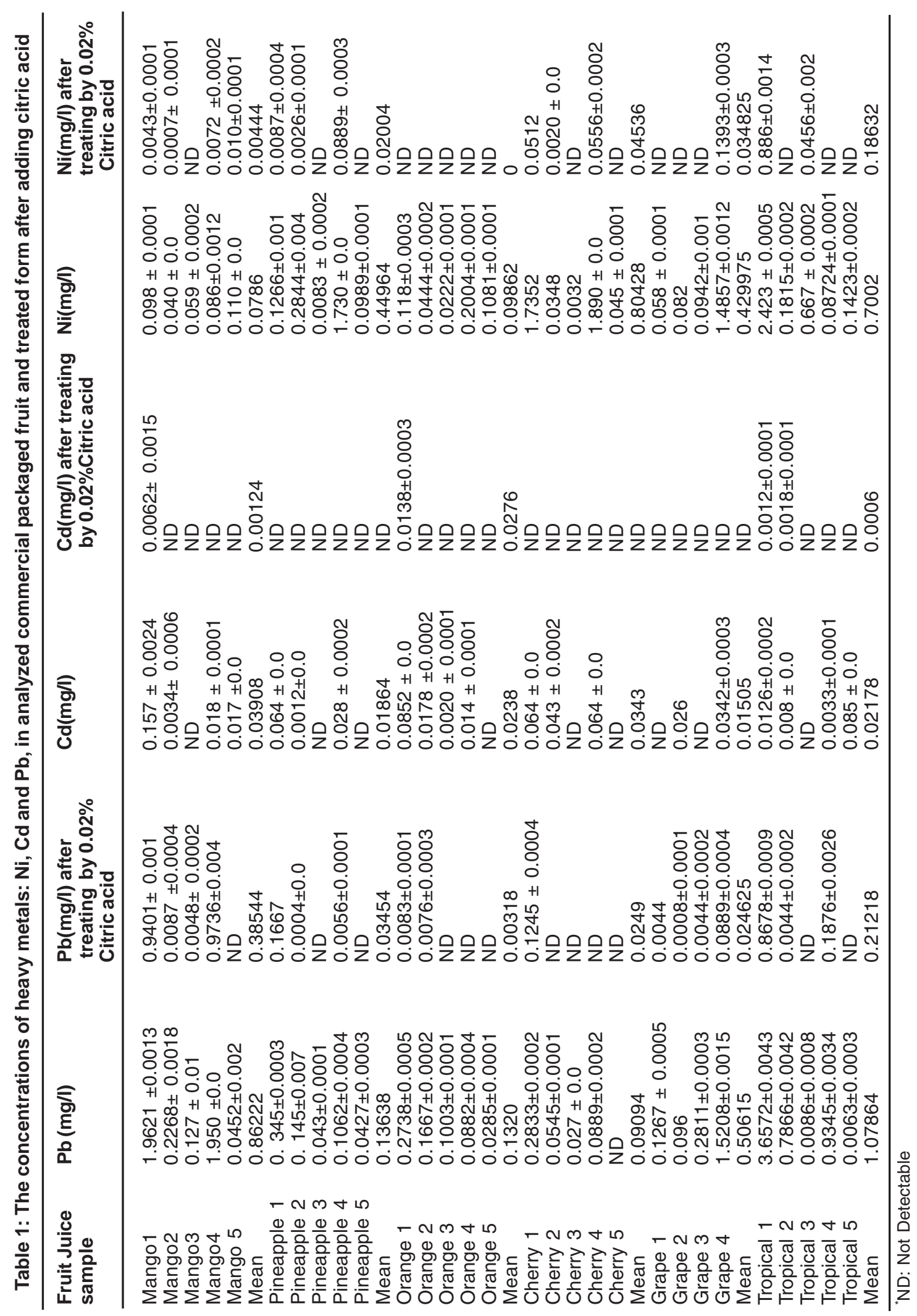


safety limits, untreated within this and some exceeding the threshold limits established by WHO and ISIRI. The maximum permissible limit for $\mathrm{Pb}$ is $0.01 \mathrm{ppm}$ set by WHO while it is $1 \mathrm{ppm}$ according to FSSAI and ISIRI safe limit 28,29 . The level of $\mathrm{Pb}$ recorded in this study was found to not be within the safety limits set by ISIRI :1 ppm for apple and orange juices and $0.3 \mathrm{ppm}$ for mango juices. The present study shows that in $76 \%$ of samples, the $\mathrm{Pb}$ content is much above this safe limit .Our study shows that the concentration of lead in fruit juices is much higher than permissible limit for mango and tropical juices but for cherry and orange samples are lower than it.

The different between mean value of $\mathrm{Pb}$ in different juice samples and WHO safe limit value is statistically significant. The concentrations of cadmium in our fruit juice sample is far below the permissible limit value after treating while before treating in some samples such as Mango1 and tropical 4 are higher than maximum permissible level. Lead toxicity causes many signs and symptoms such as abdominal pains, anemia, brain damage, anoxia, convulsion and inability to concentrate etc. ${ }^{30}$.

The grape and then pineapple juice samples in our study have the less content of cadmium among other samples and treating by citric acid cause to removal of cadmium significantly (pd" 0.003). Results revealed that The Cherry, grape and pineapple samples after treatment have no detectable cadmium content and for other samples the remained concentrations of cadmium are much lower than safe limit.

The allowed limits in drinking water for $\mathrm{Ni}$ are $100 \mu \mathrm{g} / \mathrm{L}$ (by USEPA) and $70 \mu \mathrm{g} / \mathrm{L}$ (by WHO). Results revealed that 15 values of $\mathrm{Ni}$ concentrations from investigated fruit juices before treating by citric acid were over these limits. The Ni content is much above this safe limit set by $\mathrm{WHO}$, but after treating by citric acid $0.02 \%$ they are all in the safe level. The higher Ni content observed for the untreated samples could arise from contamination either from the processing step in the factory or from an existing contamination in the drinking and pipeline water used in fruit juices processing.

The sources of fruit juices contamination are most probably either the water used in the fruit juices reconstruction or the added sugar or the imported unqualified dried fruits. $\mathrm{Cd}$ is highly toxic and responsible for several cases of poisoning through food. Small quantities of $\mathrm{Cd}$ cause adverse changes in the arteries of human kidney. It replaces Zn biochemically and causes high blood pressures, kidney damage, and so forth ${ }^{32-34}$. Because of their high toxicity, $\mathrm{As}, \mathrm{Pb}$, and $\mathrm{Cd}$ need to be quantified in food and beverages ${ }^{35}$. The analysis of $\mathrm{Pb}$ content reveals the fact that three fruit juices samples (Mango 1, Mango4, Tropical 1 and grape 4) much more exceed the allowable limits for drinking water. Taking into account that lead is less mobile than $\mathrm{Cd}$ in the soil-plant system ${ }^{36}$, the lead in fruit juice could be related to imported dried fruits in factories.

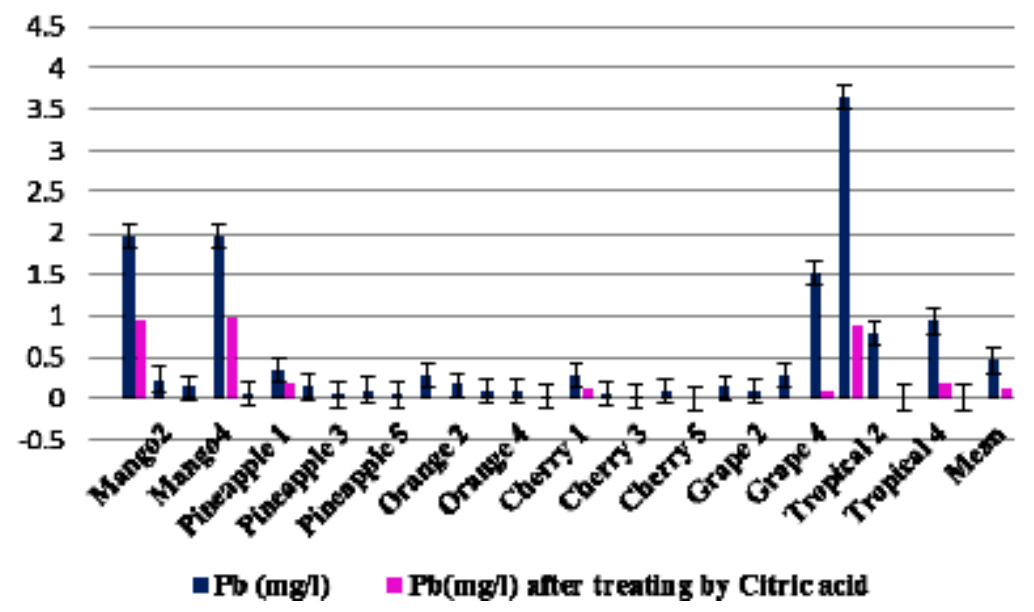

Fig. 3: Lead content(mg/L) in treated and untreated fruit juice samples 
Due to the poor screening and monitoring system in developing countries like Iran, it is very difficult to evaluate how the consumer can be affected by taking fruit juices. While most juice quality with low price sold in the market, in addition to having the properties of the fruit, is harmful to health risks as well.

Although in last several decades enough knowledge on biochemical mechanisms leading to citric acid overflow have accumulated to generally understand the phenomenon, however many details still remain unexplained. Our Findings proved that obviously the citric acid as chelating agent, act complexion with cations such as lead, cadmium and nickel. In this study with the aim of decreasing the amount of heavy metals by citric acid has proposed recovery of citric acid by precipitation of the complexes of metal-bonded- citrate. An additional advantage of this method is that complex formed by citrate has a definite crystalline structure and can be participate and removed by centrifuge or be filtered easily. This study proved that the chelating and $\mathrm{pH}$ adjusting properties of citric acid enable it to optimize the removal heavy metals especially cadmium, nickel and lead from fruit juice products by enhancing the complex formation and probably effecting on enzymes.

\section{ACKNOWLEDGEMENTS}

Financial Supports from Pharmaceutical Sciences Branch, Islamic Azad University (IAUPS) is gratefully acknowledged.

\section{REFERENCES}

1. Carson, P.; Mumford, C. Processing of fruits: ambient and low temperature processing. Second edition .2002, An imprint of Elsevier Science. Chapter Two, page 21 .Available in Site: file:///C:/Users/Pars/Downloads/ 9780387306148-c2.pdf.

2. Tormen, L.; Torres, D.P.; Dittert, I.M.; Araújo, R.G.O; Frescura, V.L.A.; Curtius, A.J. Rapid assessment of metal contamination in commercial fruit juices by inductively coupled mass spectrometry after a simple dilution. Journal of Food Composition and Analysis. 2011, 24(1), 95-102.

3. Hague, T.; Petroczi A.; Andrew, P.L.R.; Barker, J.; Naughton, D.P. Determination of metal ion content of beverages and estimation of target hazard quotients: a comparative study. Chemistry Central Journal. 2008, 2(13), 1-9.

4. Dehelean, A.; Magdas, D. A. Analysis of Mineral and Heavy Metal Content of Some Commercial Fruit Juices by Inductively Coupled Plasma Mass Spectrometry, Scientific World Journal. 2013, 2013, 215423.

5. Pramod, H. P.; Devendra, H.J . Determination of Specific Heavy Metals in Fruit Juices Using Atomic Absorption Spectroscopy (AAS), Int. J. Res. Chem. Environ. 2014, 4(3) ,163-168.

6. Beattie, J. K.; Quoc, T. N. Manganese in pineapple juices. Food Chemistry, 2000, 68(1), 37-39.

7. Krummel H.K., Gault T.W., U.S. Pat 3, 985 669, (1976)

8. Horner D.C., Electroplat. Met. Finish, 75, (1968).

9. Smith C.W., Munton C.B., Electroplat. Met. Finish. 39, 415, (1941)

10. Buchard, E.F.; Merrit, E.G. Citric Acid" In "KirkOthmers, Encyclopedia Of Chemical Technology" $3^{\text {rd }}$ Ed. , Vol. 6, P. 150, Wiley, New York (1979).

11. Berovic, M.; Legisa, M. Citric acid production. Biotechnology Annual Review, 2007, 13, 303-343.

12. Fartoosy, A.H.; Mohammad, J.N. Studying of Citric acid Efficiency in Removal of lead and copper with neutralization of Soil's Bicarbonate. Journal of Kerbala University , 2009, 7 (4).

13. Johansson, A. conversations on chelation and mineral nutrition. from internet. 2002. Page 1-4.

14. Wehmer, C.; Compt. Rend. 117, 332 (1983).

15. Wehmer C. U.S. Patent 515033 (1984) .

16. Grimoux, E.; Adam, P.; Acad,C.R. Sci. Paris 90, 1252 (1880).

17. Maz, P.; Perrier, A.; Ann. Inst. Pasteur 18, 533, (1904).

18. Crueger, W.; Crueger, A. In "Biotechnology", 
Science Tech. Inc. Sunderland, M.A., USA, (1984).

19. Mirmohammad-Makki, F.; Ziarati, P. Determination of Histamine and Heavy Metal Concentrations in Tomato pastes and Fresh Tamato (Solanum lycopersicum) in Iran. BBRA, 2014, 11(2), 537-544.

20. Yazdanparast, S.; Ziarati, P.; Asgarpanah, J. Heavy Metals and Mineral Content and Nutritive Value of Some Iranian Manna. BBRA, 2014, 11(2), 1025-1029.

21. Ziarati, P.; Arbabi, S.; Arbabi-Bidgoli, S.; Qomi, M. Determination of Lead and Cadmium Contents in (Oryza Sativa) rice samples of agricultural areas in Gilan-Iran. Intenational Journal of Farming \& Allied Sciences.2013, 2 (11), 268-271.Available on Line: http:// ijfas.com/wp-content/uploads/2013/06/268271.pdf.

22. Ziarati, P.; Khoshhal, Z., Asgarpanah, J.; Qomi, M. Contaminations of Heavy Metals in Tea Leaves, Finished Tea Products and Liqour in Gilan Province, Iran. Intl J Farm \& Alli Sci. 2013, 2 (13):,383-387. Available on Line: http://ijfas.com/wp-content/uploads/2013/07/ 383-387.pdf.

23. Ziarati, P. Determination of some heavy metals in popular medicinal plants in Tehran's market. Journal of Pharmaceutical and Health Sciences. 2012, 1(3), 31-36. Available on Line: http://www.jphs.ir.

24. Ziarati, P.; Rabizadeh, H.; Mousavi, Z.; Asgarpanah,J.; Azariun, A. The Effect of Cooking method in Potassium, Lead and Cadmium Contents in Commenly Consumed Packaged mushroom( Agaricus bisporus) in Iran. Intl J Farm \& Alli Sci. 2013, 2 (19), 728733. Available on Line: http://ijfas.com/wpcontent/uploads/2013/10/728-733.pdf.

25. Ziarati, P.; Tosifi, S. Comparing some physical and chemical properties of green olive (olea europea I.) in iran association with ecological conditions. International Journal of Plant, Animal and Environmental Sciences. 2014, 4( 2), 519-528.

26. A.O.A.C. Official method of analysis 17th edition , 2005, 14(6), pp. 877-881.

27. $A O A C$. The association of analytical communities focuses on method validation and laboratory quality assurance. Official methods of analysis 16th edition, 4th revision. 1998; vol.1,chapter 9.;

28. Ministry of Health and Family Welfare (Food Safety and Standards Authority of India) Notification New Delhi, dated the 1 st August, 2011. Available on Line : http://www. fssai.gov.in/Portals/0/Pdf/Food $\% 20$ safety $\%$ 20 and $\% 20$ standards $\% 20 \% 28$ contaminats, $\%$ 20toxins $\% 20$ and $\% 20$ residues $\% 29 \%$ 20regulation, \% 202011. pdf.

29. Institute of Standards and Industrial research of Iran (ISIRI), Numbers 117,365,507, 1634, 2234,2685,3032,3381, 5609,8788.

30. Krejpcio, Z.; Sionkowski, S.; Bartela, J. Safety of fresh fruits and juices available on the polish market as determined by heavy metal residues. Polish Journal of Environmental Studies, 2005, 14(6), 877-881.

31. Chukwujindu, M.A.; Iwegbue, Nwozo, S.O.; Ossai, E.K.; Nwajei, G.E. Heavy metal composition of some imported canned fruit drinks in Nigeria. Am J Food Technol. 2008, 3(3), 220-223.

32. Rajappa, B.; Manjappa, S.; Puttaiah, E. T. Monitoring of heavy metal concentration in groundwater of Hakinaka Taluk, India. Contemporary Engineering Sciences.2010, 3(4), 183-190.

33. Magdas, D. A. ; Dehelean, A.; Puscas, R. Isotopic and elemental determination in some Romanian apple fruit juices. The Scientific World Journal. 2012, Article ID 878242.

34. Krejpcio, Z.; Sionkowski, S.; Bartela, J. Safety of fresh fruits and juices available on the polish market as determined by heavy metal residues. Polish Journal of Environmental Studies. 2005, 14(6), 877-881.

35. Barbaste, M.; Medina, B.; Perez-Trujillo, J. P. Analysis of arsenic, lead and cadmium in wines from the Canary Islands, Spain, by ICP/ MS. Food Additives and Contaminants, 2003, 20(2), 141-148.

36. Tudoreanu, L.; Prankel, S.; Enache, L. The EU metal project-metals in the environment, toxicity and assessment of limits: cadmium. In: Clarckson PA, editor. pp. 185-196. Environmental Research Advances. chapter 9. New York, NY, USA: Nova Publishers (2007). 